\title{
Using a grazing pressure index to predict cattle damage of regenerating tree seedlings
}

\author{
MICHAEL D. PITT, REG F. NEWMAN, PHIL L. YOUWE, BRIAN M. WIKEEM, AND DEE A. QUINTON
}

Authors are associate professor, Department of Plant Science, University of British Columbia, Vancouver, Canada V6T 1Z4; assistant range scientist, British Columbia Ministry of Forests, Research Branch. Kamloops, Canada V2B 8A9; range resource agrologist, British Columbia Ministry of Forests, Kamloops, Canada V2C 2T7; research scientist, British Columbia Ministry of Forests, Research Branch, Kamloops, Canada V2B 8A9; and range management scientist, Agriculture Canada, Kamloops, Canada V2B $8 A 9$.

\section{Abstract}

This research investigated the potential for using cattle grazing pressure (AU $\mathrm{Mg}^{-1} \mathrm{ha}^{-1}$ ) and stocking rate (Animal Unit Days ha-1) for predicting basal scarring and browsing of lodgepole pine (Pinus contorta Dougl.) seedlings on cutblocks in southern British Columbia from 1989 to 1992 . Cattle browsing on lodgepole pine seedlings occurred almost exclusively during the first 2 years of grazing. Browsing increased $\left(P<0.05 ; r^{2}=0.71\right)$ with increasing stocking rate only during the first year of grazing. Browsing increased with increasing grazing pressure in $1989\left(\mathbf{P}<0.05 ; r^{2}=\right.$ $0.38)$ and $1990\left(P<0.05 ; r^{2}=0.39\right)$. Basal scarring peaked during the second year of grazing, but was correlated $\left(P<0.05 ; r^{2}=0.79\right)$ with stocking rate only during the first year of grazing. Increasing grazing pressure was associated with higher $(P<0.05)$ basal scarring during all 4 years of the study, and likely better predicts trampling damage than does stocking rate, particularly during the first year of grazing. Basal scarring during 1989 generally increased to $>10 \%$ of sample trees when grazing pressure exceeded 12.0 $\mathrm{AU} \mathrm{Mg}^{-1} \mathrm{ha}^{-1}$. This threshold grazing pressure value of 12.0 $\mathrm{AU} \mathrm{Mg} \mathrm{Ma}^{-1} \mathrm{ha}^{-1}$, however, cannot likely be extrapolated directly to other sites. Grazing pressure values and associated basal scarring are unquestionably influenced by many factors (e.g., pasture size, kind of grazing animal, forage species, tree height, water availability, topography, and weather patterns during the grazing period). Nonetheless, our work provides evidence that grazing pressure provides a useful index for predicting the potential for trampling damage of lodgepole pine seedlings by cattle.

Key Words: British Columbia, cutblocks, forest grazing, lodgepole pine

An increasing proportion of cattle grazing in British Columbia occurs on cutblocks (e.g., clearcuts) seeded to domestic forages (Pitt 1989). Virtually all these cutblock seedings intend to provide only temporary grazing opportunities for the Provincial beef industry until canopy closure reduces forage production.

Research was supported in part by the British Columbia Agricultural Sciences Co-ordinating Committee, the Canada-British Columbia Forest Resource Development Agreement, and the Science Council of British Columbia. Logistic and field support were provided by Ainsworth Lumber (1987) Ltd., and the Indian Gardens Ranch. Kevin Cameron and Ross Nicholson aided with statistical analyses. George Powell provided editorial comments on the manuscript.

Manuscript accepted 15 March 1997.
A major argument against cattle grazing of seeded cutblocks is that trampling and browsing damage contribute significantly to regenerating areas being classified as Not Satisfactorily Restocked (NSR). If this classification exists 7 years following logging, then forest licensees become liable for reduced annual timber harvest (Province of British Columbia 1995). Moreover, the forest licensees are also responsible for replanting cutblocks classified as NSR.

Foresters are, therefore, often reluctant to accept forage seeding or cattle grazing on regenerating cutblocks until trees reach the "free-growing" stage. In British Columbia, this stage usually occurs 12-15 years following either tree seedling planting or natural regeneration (Province of British Columbia 1995). Trees are then considered to be sufficiently well-established that competition from seeded forages and damage from cattle grazing become negligible; unfortunately, the optimal time for successful forage establishment and cattle production has already passed. Continued, successful integration of cattle production on cutblocks in British Columbia, therefore, remains feasible only if grazing management minimizes damage or mortality to tree seedlings.

McLean and Clark (1980) documented that cattle damage to naturally regenerating lodgepole pine (Pinus contorta Dougl.) and Engelmann spruce (Picea engelmannii Parry) was negligible where numbers and movements of cattle were strictly controlled. Similarly, Nordstrom (1984) concluded that where extensive cattle damage had occurred in regenerating forests in British Columbia's southern interior, poor cattle management was usually at fault. Both authors also noted that most damage to young trees occurred from inadvertent trampling rather than from direct browsing.

In a review of cattle/tree interactions in southern British Columbia, Pitt (1989) reported that specific grazing management suggestions varied from intense grazing with high forage use for short grazing periods, moderate forage use for short grazing periods, and moderate forage use for extended grazing periods. Much disagreement remains, and new research is required to establish optimal grazing management programs on regenerating cutblocks.

Previous research on forest grazing in British Columbia has isolated either stocking density (Animal Units ha ${ }^{-1}$ ) or stocking rate (Animal Unit Days ha $\mathrm{ha}^{-1}$ ) to determine potential impacts on regenerating conifers (Pitt 1989). Stocking density, however, simply describes the animal-to-land relationship at an instant of time (Booysen 1967), and likely does not provide an effective prediction of trampling or browsing damage throughout grazing periods of variable duration. 
Grazing pressure (AU kg-1 of available forage) describes the ratio of animal demand per unit mass of forage at any instant in time (Scarnecchia 1985). Scarnecchia et al. (1985) showed that grazing time of heifers increased dramatically as forage availability declined. Presumably, grazing pressure also increased as forage availability declined. Increased grazing time also implies that animals spend more time walking through the pasture searching for forage. On regenerating cutblocks, more trees may suffer trampling damage as forage supply diminishes, followed by increased grazing pressure, and increased foraging time. Compared to stocking rate, therefore, grazing pressure may provide a more useful prediction or measure of the potential impacts of cattle grazing on tree seedling damage.

This study, then, tests the hypothesis that grazing pressure provides a better index than does stocking rate for predicting conifer tree seedling browsing and trampling damage. If this hypothesis is true, then cattle damage of conifer tree seedlings will positively correlate with increasing grazing pressure. Specifically, there will be a threshold of grazing pressure, beyond which trampling damage will increase substantially. Alternatively, tree browsing and trampling damage will not correlate significantly with stocking rate. We assessed this general theory within a broader study that investigated the relationships among cattle grazing intensity (50 and $80 \%$ forage use), forage seeding rates $\left(0,3\right.$, and $\left.12 \mathrm{~kg} \mathrm{ha}^{-1}\right)$, and the growth and survival of lodgepole pine (Wikeem et al. 1991.)

\section{Study Area and Methods}

The study was conducted in 6 pastures in the Very Dry Cool Montane Spruce (Lloyd et al. 1990) biogeoclimatic subzone (MSxk) at Tunkwa Lake $\left(50^{\circ} 33^{\prime} \mathrm{N}, 120^{\circ} 56^{\prime} \mathrm{W}\right)$, near Kamloops, British Columbia. Annual precipitation at Highland Valley $\left(50^{\circ} 31^{\prime} \mathrm{N}, 121^{\circ} 1^{\prime} \mathrm{W} ; 1,554 \mathrm{~m}\right), 5 \mathrm{~km}$ southwest of the site, averages $355 \mathrm{~mm}$, with peaks in December $(45 \mathrm{~mm})$ and June (36 $\mathrm{mm})$. Highest mean daily maximum temperatures occur in July $\left(20.5^{\circ} \mathrm{C}\right)$; lowest daily minimum temperatures occur in January (-12.6 ${ }^{\circ}$ C) (Atmospheric Environment Service 1990). May-October weather data recorded at the site over the course of the study showed mean daily temperatures of $9.0^{\circ} \mathrm{C}$ (CR21 Micrologger; Campbell Scientific Inc.; Logan, Utah).

The site occurred at $1,400 \mathrm{~m}$ elevation with a NW aspect and a $5-10 \%$ slope. The area was clearcut and windrowed in October and November 1986. The windrows were burned in November 1987 , and then drag-scarified to achieve $25 \%$ mineral soil disturbance. Before logging, the forest overstory consisted of lodgepole pine and Engelmann spruce in approximately equal proportions. Pinegrass (Calamagrostis rubescens Buckl.), heart-leaved arnica (Arnica cordifolia Hook.), and birch-leaved spirea (Spiraea betulifolia Pall.) characterized the understory. Soils are predominantly dystric brunisols (cryochrepts), with luvisols (cryoboralfs) occurring in more moist areas.

The cutblock was aerially seeded in May 1988 to a forage mix that included (by weight) $35 \%$ orchardgrass (Dactylis glomerata L.), 5\% timothy (Phleum pratense L.), 40\% alsike clover (Trifolium hybridum L.), and $20 \%$ white Dutch clover ( $T$. repens L.). Two strips, approximately 10 ha each, were seeded at 3 and $12 \mathrm{~kg} \mathrm{ha}^{-1}$, respectively; a 10-ha control strip remained unseeded. These variable seeding rates comprised part of the larger study (Wikeem et al. 1991.). For the grazing pressure component of the study, these variable seeding rates have no relevancy, but serve simply to identify and distinguish among the research pastures.

The cutblock was planted primarily with lodgepole pine in May 1988 at a stocking of 1,400 stems $\mathrm{ha}^{-1}$, at $2.7-\mathrm{m}$ spacings. Seedlings were 1-year-old nursery-grown stock lodgepole pine from a common seedlot. At the beginning of the grazing pressure study in 1989 , tree seedlings averaged $22.4 \mathrm{~cm}$ in height, and 5.2 $\mathrm{mm}$ in diameter.

In June 1988, each seeding treatment was fenced in half to produce six, 5-ha pastures $(100 \times 500 \mathrm{~m})$ for grazing, with the longitudinal axis parallel to the slope. A 0.5 -ha exclosure was constructed in the middle of each seeding treatment to provide ungrazed controls. Ten 50-m transects were systematically located in each pasture parallel to slope contours. Transects were centrally located and spaced $25 \mathrm{~m}$ apart to produce a huffer strip of not less than $30 \mathrm{~m}$ between the transects and the enclosure fences. Within the 0.5 -ha grazing exclosures, $50-\mathrm{m}$ transects were spaced $5 \mathrm{~m}$ apart to provide a $12.5-\mathrm{m}$ buffer strip on 2 sides of the exclosure, with a 10 -m buffer strip on the other 2 sides.

\section{Grazing Pressure}

Ten pine seedlings were randomly selected adjacent to each of the 10 transects in each experimental unit $\left(n=100\right.$ pasture $\left.^{-1}\right)$. The following parameters were measured to determine the relationships between grazing pressure, stocking rate, and seedling damage: available standing crop ( $\mathrm{kg} \mathrm{ha}^{-1}$ of current annual plant growth) immediately before cattle turnout; numbers and extent of trees damaged (basal scarring and browsing) immediately before cattle turnout; available standing crop during the period of cattle grazing $(7,14,21$, and 30 days); and numbers and extent of trees damaged (basal scarring and browsing) during the period of cattle grazing ( $7,14,21$, and 30 days).

Browsing included terminal leaders and lateral branches. For basal scarring, we measured percent of stem circumference and length of scar. We also recorded position of the scar on the stem to distinguish between new and old scarring between sample periods. Basal scarring by cattle trampling left ragged scar margins and slightly exfoliating bark. This kind of wound was easily distinguished from scarring by rodent gnawing, which tended to leave beveled scar margins without exfoliating bark. Except for rodents, we attributed all browsing and scarring during the grazing period to cattle.

Available standing crop was determined within ten, $1-\mathrm{m} \times 50-\mathrm{m}$ macroplots located along the 10 transects within each pasture. At each of the 5 sample dates year ${ }^{-1}$, one, $1.0-\mathrm{m}^{2}$ plot was randomly selected from each macroplot and clipped to a 5-cm stubble height. No plot was sampled more than once during the study. Ten $1.0-\mathrm{m}^{2}$ plots were also clipped to a $5-\mathrm{cm}$ stubble height in the ungrazed exclosure. Available standing crop was oven-dried to a constant weight at $70^{\circ} \mathrm{C}$, and weighed to the nearest $0.1 \mathrm{~g}$. Forage use within each successive sampling period was determined by comparing available standing crop between the grazed and ungrazed areas.

Grazing pressure was also determined at $0,7,14,21$, and 30 days during the grazing period. Grazing pressure was expressed as $\mathrm{AUs}$ relative to available forage ( $\left.\mathrm{AU} \mathrm{Mg}{ }^{1} \mathrm{ha}^{-1}\right)$.

\section{Cattle Numbers}

Crossbred Herefords (Beef Booster; Alberta, Canada) were grazed from mid-July to mid-August from 1989 to 1992 . Cowcalf pairs (AUs) were established annually to achieve 50 and $80 \%$ use of available forage in each pasture, based on an estimated 
dry-matter consumption plus trampling of $15 \mathrm{~kg} \mathrm{day}^{-1}$ for each cow-calf pair. The number of cow-calf pairs in each pasture varied annually from 3 to 32 , according to available standing crop before cattle turnout, estimated forage growth during the grazing period, and desired use. Cow-calf pairs were adjusted downward during the grazing period in 3 pastures in 1990 to prevent actual forage use from exceeding desired forage use. All cows had previous experience grazing on cutblocks. Weights of cows and calves at the beginning of the grazing period averaged $476 \mathrm{~kg}$ and $133 \mathrm{~kg}$, respectively.

\section{Statistical Analysis}

The 6 pastures, with seeding and grazing treatments allocated within a randomized complete block design, represented distinct, point estimates of tree damage and grazing; consequently, grazing pressure and stocking rate were derived separately for all 6 pastures for each of the 4 years. The relationships between tree damage (browsing and basal scarring), grazing pressure, and stocking rate were evaluated with linear regressions. Grazing pressure increased between grazing intervals; consequently, regressions with scarring and browsing were based on data for each grazing interval within the 6 pastures. Because AUs generally remained constant between grazing intervals within the 6 pastures, regressions of scarring and browsing on stocking rate were based on the entire 30 -day grazing period.

Grazing pressure, browsing, and scarring were sampled from multivariate populations. Linear relationships among these parameters may not necessarily describe repeatable predictions for other sites in other years. We have, therefore, presented these relationships as scaller diagrams rather than regression equations. These scatter diagrams also more effectively describe thresholds of grazing pressure and stocking rates beyond which tree seedling damage increases substantially.

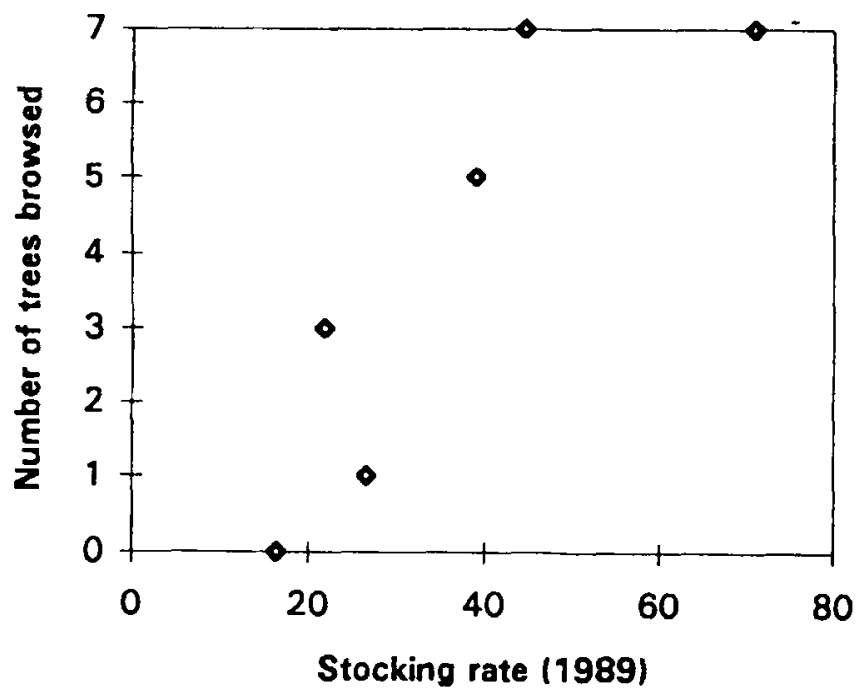

Fig. 1. Relationship $\left(P<0.05 ; r^{2}=0.71\right)$ of stocking rate (Animal Unit Days $\mathrm{ha}^{-1}$ ) and number of 100 sample trees browsed at Tunkwa Lake, Kamloops, British Columbia (1989).
Table 1. Animal units (AUs), grazing pressure, and number of damaged trees in pasture 1 (4.95 ha), 1989-1992, at Tunkwa Lake, Kamloops, British Columbia (Projected forage use $=50 \%$; Seeding rate $=3.0 \mathrm{~kg} / \mathrm{ha}$ ).

\begin{tabular}{|c|c|c|c|c|}
\hline \multirow[t]{2}{*}{ Grazing Interval } & \multirow[t]{2}{*}{ AUs } & \multirow[t]{2}{*}{ Grazing Pressure } & \multicolumn{2}{|c|}{ Trees Damaged } \\
\hline & & & Scarred & Browsed \\
\hline nen & 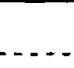 & 1989. & \multicolumn{2}{|c|}{$\cdots(\mathrm{No}) \cdots$} \\
\hline $0-7$ days & 4 & 3.3 & 4 & 1 \\
\hline 8-14 days & 4 & 6.1 & 7 & 0 \\
\hline 15-21 days & 4 & 5.7 & 4 & 2 \\
\hline $22-30$ days & 4 & 6.8 & 17 & 0 \\
\hline \multicolumn{5}{|c|}{ 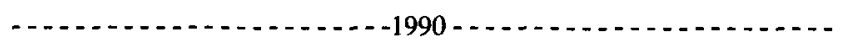 } \\
\hline $0-7$ days & 10 & 10.1 & 13 & 1 \\
\hline $8-14$ & 10 & 8.2 & 6 & 1 \\
\hline 15-21 days & 10 & 10.7 & 22 & 0 \\
\hline $22-30$ days & 10 & 29.1 & 32 & 0 \\
\hline \multicolumn{5}{|c|}{ (2, } \\
\hline 0-7 days & 4 & 4.0 & 4 & 0 \\
\hline 8-14 days & 4 & 12.9 & 7 & 0 \\
\hline $15-21$ days & 4 & 9.1 & 5 & 0 \\
\hline 22-30 days & 4 & 11.9 & 8 & 0 \\
\hline \multicolumn{5}{|c|}{ - } \\
\hline $0-7$ days & 6 & 33.8 & 3 & 0 \\
\hline 8-14 days & 6 & 23.4 & 7 & 0 \\
\hline 15-21 days & 6 & 32.4 & 0 & 0 \\
\hline $22-30$ days & 6 & 37.9 & 10 & 0 \\
\hline
\end{tabular}

\section{Results}

\section{Browsing}

Browsing occurred almost exclusively during the first 2 years of grazing (Tables 1-6). Twenty-ihree of 600 sample trees were browsed in 1989, and 14 were browsed in 1990. Only 1 of 500 sample trees suffered browsing in 1991. No browsing occurred in 1992. Browsing increased $\left(P<0.05 ; r^{2}=0.71\right)$ as stocking rate increased only during the first year of grazing (Fig. 1).

In the 11 pasture-year combinations where browsing occurred, browsing correlated $(\mathrm{P}<0.05)$ with grazing pressure on only 5

Table 2. Animal units (AUs), grazing pressure, and number of damaged trees in pasture 2 (4.85 ha), 1989-1992, at Tunkwa Lake, Kamloops, British Columbia. (Projected forage use $=80 \%$; Seeding rate $=3.0 \mathrm{~kg} / \mathrm{ha}$ ).

\begin{tabular}{|c|c|c|c|c|}
\hline \multirow[t]{2}{*}{ Grazing Interval } & \multirow[t]{2}{*}{ AUs } & \multirow[t]{2}{*}{ Grazing Pressure } & \multicolumn{2}{|c|}{ Trees Damaged } \\
\hline & & & Scarred & Browsed \\
\hline$\cdots$ & $\ldots$ & - 1989 & \multicolumn{2}{|c|}{$\ldots(\mathrm{No}) \cdots$} \\
\hline $0-7$ days & 7 & 8.2 & 3 & 0 \\
\hline $8-14$ days & 7 & 14.2 & 5 & 3 \\
\hline 1521 days & 7 & 16.9 & 18 & 1 \\
\hline 22-30 days & 7 & 28.2 & 14 & 1 \\
\hline \multicolumn{5}{|c|}{ 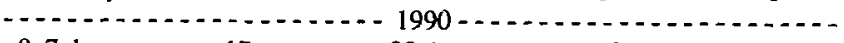 } \\
\hline $0-7$ days & 17 & 23.4 & 20 & 0 \\
\hline $8-14$ days & 17 & 20.9 & 18 & 0 \\
\hline 15-21 days & 17 & 30.4 & 25 & 0 \\
\hline $22-30$ days & 17 & 125.6 & 11 & 1 \\
\hline \multirow{4}{*}{\multicolumn{5}{|c|}{$\begin{array}{l}8-7 \text { days } \\
8-14 \text { days } \\
15-21 \text { days } \\
22-30 \text { days }\end{array}$}} \\
\hline & & & & \\
\hline & & & & \\
\hline & & & & \\
\hline \multicolumn{5}{|l|}{ 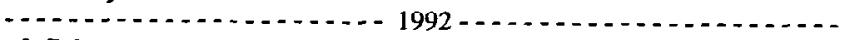 } \\
\hline $0-7$ days & 9 & 20.9 & 3 & 0 \\
\hline 8-14 days & 9 & 20.9 & 6 & 0 \\
\hline $15-21$ days & 9 & 33.0 & 0 & 0 \\
\hline $22-30$ days & 9 & 125.6 & 5 & 0 \\
\hline
\end{tabular}


Table 3. Animal units (AUs), grazing pressure, and number of damaged trees in pasture 3 (4.85 ha), 1989-1992, at Tunkwa Lake, Kamloops, British Columbia. (Projected forage use $=50 \%$; Seeding rate $=12.0 \mathrm{~kg} / \mathrm{ha}$ ).

\begin{tabular}{|c|c|c|c|c|}
\hline \multirow[t]{2}{*}{ Grazing Interval } & \multirow[t]{2}{*}{ AUs } & \multirow[t]{2}{*}{ Grazing Pressure } & \multicolumn{2}{|c|}{ Trees Damaged } \\
\hline & & & Scarred & Browsed \\
\hline & & & \multicolumn{2}{|c|}{$\ldots(\mathrm{No}) \ldots$} \\
\hline \multicolumn{5}{|c|}{ - } \\
\hline 0-7 days & 8 & 5.7 & 5 & 0 \\
\hline $8-14$ days & 8 & 8.4 & 6 & 3 \\
\hline 15-21 days & 8 & 11.5 & 17 & 2 \\
\hline $22-30$ days & 8 & 12.5 & 12 & 2 \\
\hline \multicolumn{5}{|c|}{ - } \\
\hline $0-7$ days & 19 & 18.4 & 16 & 1 \\
\hline $8-14$ days & 19 & 23.2 & 28 & 0 \\
\hline 15-21 days & 19 & 34.6 & 25 & 2 \\
\hline $22-30$ days & 19 & 110.9 & 33 & 2 \\
\hline \multicolumn{5}{|c|}{$\ldots$} \\
\hline 0-7 days & 4 & 2.0 & 4 & 0 \\
\hline $8-14$ days & 4 & 10.2 & 4 & 0 \\
\hline 15-21 days & 4 & 6.3 & 1 & 0 \\
\hline 22-30 days & 4 & 14.3 & 7 & 0 \\
\hline \multicolumn{5}{|c|}{ - } \\
\hline $0-7$ days & 6 & 30.8 & 4 & 0 \\
\hline 8-14 days & 6 & 16.4 & 3 & 0 \\
\hline $15-21$ days & 6 & 19.1 & 0 & 0 \\
\hline $22-30$ days & 6 & 21.6 & 5 & 0 \\
\hline
\end{tabular}

occasions (Table 7). When averaged over all pastures within years, browsing increased with increasing grazing pressure in both 1989 and $1990(\mathrm{P}<0.05)$ (Fig. 2). The regression equations, however, accounted for only $38 \%$ and $39 \%$ of the variation, respectively.

\section{Basal Scarring}

Greatest basal scarring occurred during the first 2 years of grazing. An average of 42 and $70 \%$ of trees per pasture were scarred in 1989 and 1990 , respectively, compared to only $23 \%$ in 1991 and $13 \%$ in 1992.

When averaged over the entire 30 -day grazing period, basal scarring increased $\left(\mathrm{P}<0.05 ; \mathrm{r}^{2}=0.79\right)$ as stocking rate increased

Table 4. Animal units (AUs), grazing pressure, and number of damaged trees in pasture 4 (4.95 ha), 1989-1992, Tunkwa Lake, Kamloops, British Columbia. (Projected forages use $=80 \%$; Seeding rate $=12.0 \mathrm{~kg} / \mathrm{ha}$ ).

\begin{tabular}{|c|c|c|c|c|}
\hline \multirow[t]{2}{*}{ Grazing Interval } & \multirow[t]{2}{*}{ AUs } & \multirow[t]{2}{*}{ Grazing Pressure } & \multicolumn{2}{|c|}{ Trees Damaged } \\
\hline & & & Scarred & Browsed \\
\hline & & & \multicolumn{2}{|c|}{$\ldots . .(\mathrm{No}) \ldots$} \\
\hline \multicolumn{5}{|c|}{ - } \\
\hline $0-7$ days & 13 & 9.2 & 7 & 1 \\
\hline $8-14$ days & 13 & 13.5 & 25 & 0 \\
\hline 15-21 days & 13 & 22.0 & 14 & 4 \\
\hline $22-30$ days & 13 & 25.5 & 22 & 2 \\
\hline \multicolumn{5}{|c|}{ 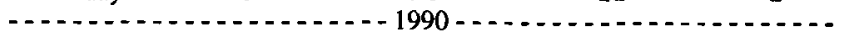 } \\
\hline 0-7 days & 32 & 23.4 & 20 & 0 \\
\hline $8-14$ days & 32 & 31.7 & 18 & 0 \\
\hline 15-21 days & 29 & 77.4 & 6 & 0 \\
\hline 22-30 days & 10 & 172.9 & 12 & 5 \\
\hline \multicolumn{5}{|c|}{ 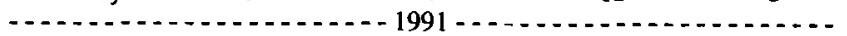 } \\
\hline $0-7$ days & 6 & 10.1 & 5 & 0 \\
\hline $8-14$ days & 6 & 7.2 & 1 & 0 \\
\hline 15-21 days & 6 & 22.0 & 2 & $\mathbf{0}$ \\
\hline $22-30$ days & 6 & 31.3 & 3 & 0 \\
\hline \multicolumn{5}{|c|}{ 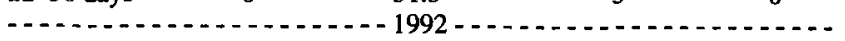 } \\
\hline $0-7$ days & 9 & 39.6 & 1 & 0 \\
\hline 8-14 days & 9 & 24.8 & 2 & 0 \\
\hline 15-21 days & 9 & 49.2 & 0 & 0 \\
\hline $22-30$ days & 9 & 108.2 & 1 & 0 \\
\hline
\end{tabular}

Table 5. Animal units (AUs), grazing pressure, and number of damaged trees in pasture 5 (4.95), 1989-1992, at Tunkwa Lake, Kamloops, British Columbia. (Projected forage use $=50 \%$; No seeding).

\begin{tabular}{|c|c|c|c|c|}
\hline \multirow[t]{2}{*}{ Grazing Interval } & \multirow[t]{2}{*}{ AUs } & \multirow[t]{2}{*}{ Grazing Pressure } & \multicolumn{2}{|c|}{ Trees Damaged } \\
\hline & & & Scarred & Browsed \\
\hline & & & \multicolumn{2}{|c|}{$\ldots-\ldots(\mathrm{No})-\ldots$} \\
\hline \multicolumn{5}{|c|}{ - } \\
\hline $0-7$ days & 3 & 5.1 & 2 & 0 \\
\hline 8-14 days & 3 & 6.5 & 8 & 0 \\
\hline 15-21 days & 3 & 7.9 & 5 & 0 \\
\hline $22-30$ days & 3 & 7.4 & 6 & 0 \\
\hline \multicolumn{5}{|c|}{$1990 \ldots-1-1, \ldots$} \\
\hline 0-7 days & 9 & 34.0 & 9 & 0 \\
\hline 8-14 days & 9 & 41.5 & 9 & 1 \\
\hline 15-21 days & 6 & 40.7 & 8 & 0 \\
\hline $22-30$ days & 2 & 34.0 & 20 & 0 \\
\hline \multicolumn{5}{|c|}{ - $1991-\ldots$} \\
\hline $0-7$ days & 4 & 12.3 & 4 & 0 \\
\hline $8-14$ days & 4 & 20.8 & 8 & 0 \\
\hline 15-21 days & 4 & 23.0 & 6 & 1 \\
\hline 22-30 days & 4 & 87.1 & 15 & 0 \\
\hline \multicolumn{5}{|c|}{ - } \\
\hline 0-7 days & 3 & 21.9 & 4 & 0 \\
\hline $8-14$ days & 3 & 14.6 & 3 & 0 \\
\hline $15-21$ days & 3 & 24.0 & 0 & 0 \\
\hline $22-30$ days & 3 & 18.6 & 3 & 0 \\
\hline
\end{tabular}

only during the first year of grazing (Fig. 3). Within each pasture, however, basal scarring was not affected by stocking rate. Tree damage varied greatly among the 4 grazing intervals in all 6 pastures even though stocking rate per pasture generally remained constant between sampling periods (Tables 1-6).

Basal scarring was related more to grazing pressure than to stocking rate. Basal scarring increased $(P<0.05)$ with grazing pressure in all 6 pastures during the first year of grazing (Table 7 ). In 1989, greatest basal scarring (68\%) occurred in pasture 4 (Table 4), in association with the third highest peak grazing pressure (25.5 AU $\mathrm{Mg}^{-1} \mathrm{ha}^{-1}$ ). Highest peak grazing pressure (38.0 $\mathrm{AU} \mathrm{Mg} \mathrm{Mg}^{-1} \mathrm{ha}^{-1}$ occurred in pasture 6 (Table 6), which also pro-

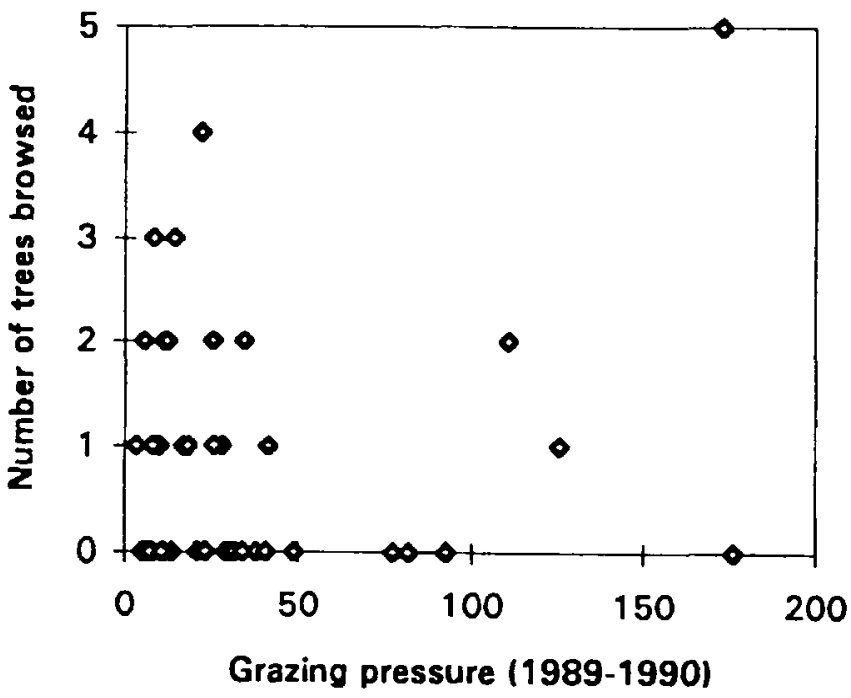

Fig. 2. Relationship $(P<0.05)$ of grazing pressure $\left(A U \mathrm{Mg}^{-1} \mathrm{ha}^{-1}\right)$ and number of 100 sample trees browsed at Tunkwa Lake, Kamloops, British Columbia in $1989\left(r^{2}=0.38\right)$ and $1990\left(r^{2}=0.39\right)$. 
Tahle 6. Animal units (AUs), grazing pressure, and number of damaged trees in pasture 6 (5.05 ha), 1989-1992, at Tunkwa Lake, Kamloops, British Columbia. (Projected forage use $=80 \%$; No seeding).

\begin{tabular}{|c|c|c|c|c|}
\hline \multirow[t]{2}{*}{ Grazing Interval } & \multirow[t]{2}{*}{$\mathrm{AUs}$} & \multirow[t]{2}{*}{ Grazing Pressure } & \multicolumn{2}{|c|}{ Trees Damaged } \\
\hline & & & Scarred & Browsed \\
\hline & & & \multicolumn{2}{|c|}{$\ldots-\ldots(\mathrm{No}) \ldots$} \\
\hline \multicolumn{5}{|c|}{$1989-2 \ldots$} \\
\hline $0-7$ days & 5 & 11.0 & 9 & 0 \\
\hline 8-14 days & 5 & 11.4 & 6 & 0 \\
\hline 15-21 days & 5 & 25.8 & 14 & 1 \\
\hline $22-30$ days & 5 & 38.0 & 20 & 0 \\
\hline \multicolumn{5}{|c|}{ ـ } \\
\hline $0-7$ days & 12 & 48.8 & 19 & 0 \\
\hline 8-14 days & 12 & 82.0 & 17 & 0 \\
\hline 15-21 days & 10 & 92.8 & 28 & 0 \\
\hline $22-30$ days & 8 & 176.2 & 5 & 0 \\
\hline \multicolumn{5}{|c|}{ - } \\
\hline $0-7$ days & 5 & 12.8 & 3 & 0 \\
\hline $8-14$ days & 5 & 13.9 & II & 0 \\
\hline 15-21 days & 5 & 40.8 & 8 & 0 \\
\hline $22-30$ days & 5 & 104.7 & 15 & 0 \\
\hline \multicolumn{5}{|c|}{ 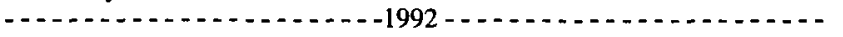 } \\
\hline 0.7 days & 4 & 32.5 & 2 & $\mathbf{0}$ \\
\hline $8-14$ days & 4 & 26.7 & 15 & 0 \\
\hline 15-21 days & 4 & 39.0 & 0 & 0 \\
\hline $22-30$ days & 4 & 20.7 & 1 & 0 \\
\hline
\end{tabular}

duced the second highest percentage (49) of scarred trees. In contrast, the lowest percentage (21) of trees scarred by cattle occurred in pasture 5 (Table 5), where peak grazing pressure reached only $7.9 \mathrm{AU} \mathrm{Mg}^{-1} \mathrm{ha}^{-1}$. Lowest peak grazing pressure (6.8 $\mathrm{AU} \mathrm{Mg} \mathrm{Ma}^{-1}$ ) in 1989 occurred in pasture 1 (Table 1), where the second lowest percent (32) of trees suffered basal scarring.

The percentage of trees scarred by cattle in 1989 generally increased $\left(P<0.05 ; r^{2}=0.81\right)$ substantially whenever grazing pressure exceeded approximately $12 \mathrm{AU} \mathrm{Mg}^{-1} \mathrm{ha}^{-1}$ (Fig. 4). For example, grazing pressure exceeded $12 \mathrm{AU} \mathrm{Mg}^{-1} \mathrm{ha}^{-1}$ for 9 of the 24 pasture grazing intervals in 1989. With only 1 exception, between 12 and $25 \%$ of trees per pasture were scarred whenever grazing pressure surpassed this threshold. Grazing pressure

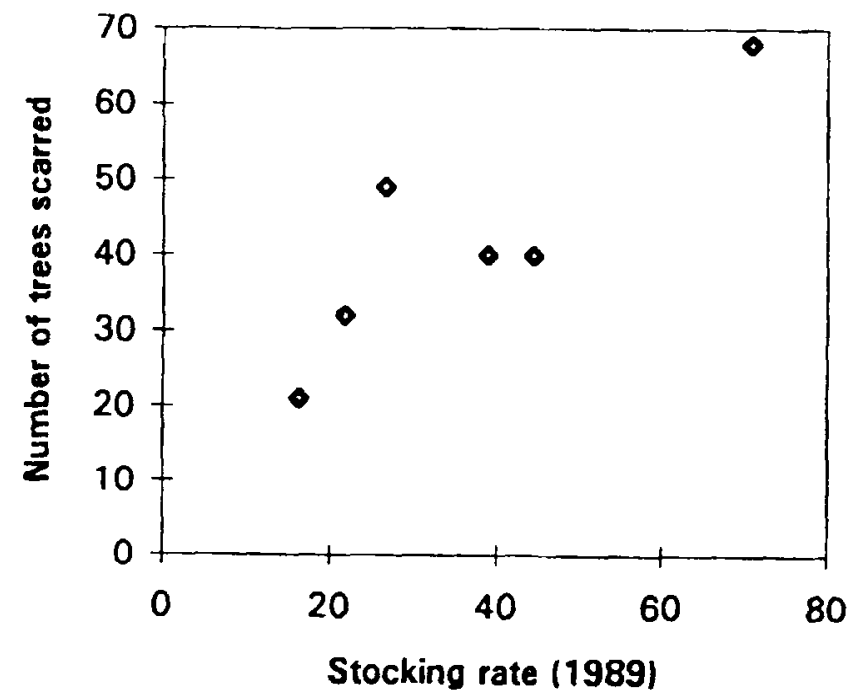

Fig. 3. Relationship (P $<0.05 ; r^{2}=0.79$ ) of stocking rate (Animal Unit Days $\mathrm{ha}^{-1}$ ) and number of 100 sample trees scarred at Tunkwa Lake, Kamloops, British Columbia (1989).

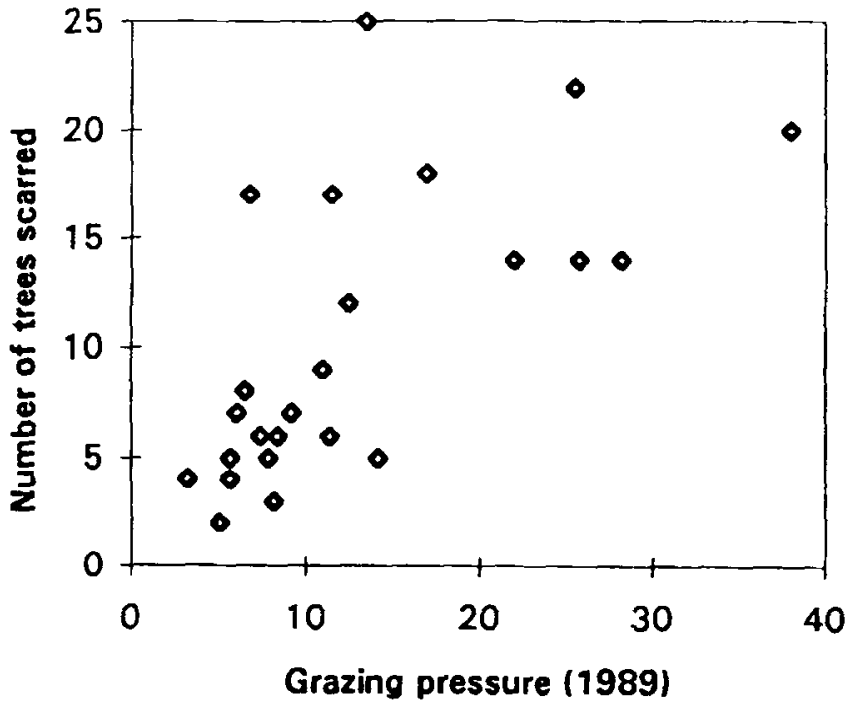

Fig. 4. Relationship $\left(\mathrm{P}<0.05 ; \mathrm{r}^{2}=0.81\right)$ of grazing pressure ( $\mathrm{AU} \mathrm{Mg}^{-1}$ $\mathrm{ha}^{-1}$ ) and number of 100 sample trees scarred at Tunkwa Lake, Kamloops, British Columbia (1989).

remained below $12 \mathrm{AU} \mathrm{Mg}^{-1} \mathrm{ha}^{-1}$ for 15 of the 24 pasture grazing intervals during 1989 (Tables 1-6). For most of these instances (13 of 15), less than $10 \%$ of the trees suffered basal scarring. In 1 of the 2 exceptions when more than $10 \%$ of the trecs were scarred by cattle trampling, grazing pressure equaled $11.5 \mathrm{AU} \mathrm{Mg}^{-1} \mathrm{ha}^{-1}$.

After the initial year of grazing, however, grazing pressure provided less consistent relationships with basal scarring (Table 7). Although basal scarring increased with grazing pressure in 1990 $(\mathrm{P}<0.05)$ the relationship explained only $39 \%$ of the variation. In 1991 , basal scarring also increased $\left(P<0.05 ; r^{2}=0.69\right)$ with grazing pressure, although the relationship resulted primarily from 2 extreme data points. Cattle trampling scarred $15 \%$ of the trees per pasture when grazing pressure equaled 87.1 and 104.7 $\mathrm{AU} \mathrm{Mg} \mathrm{Ma}^{-1} \mathrm{ha}^{-1}$. For the remaining pasture grazing intervals, graz-

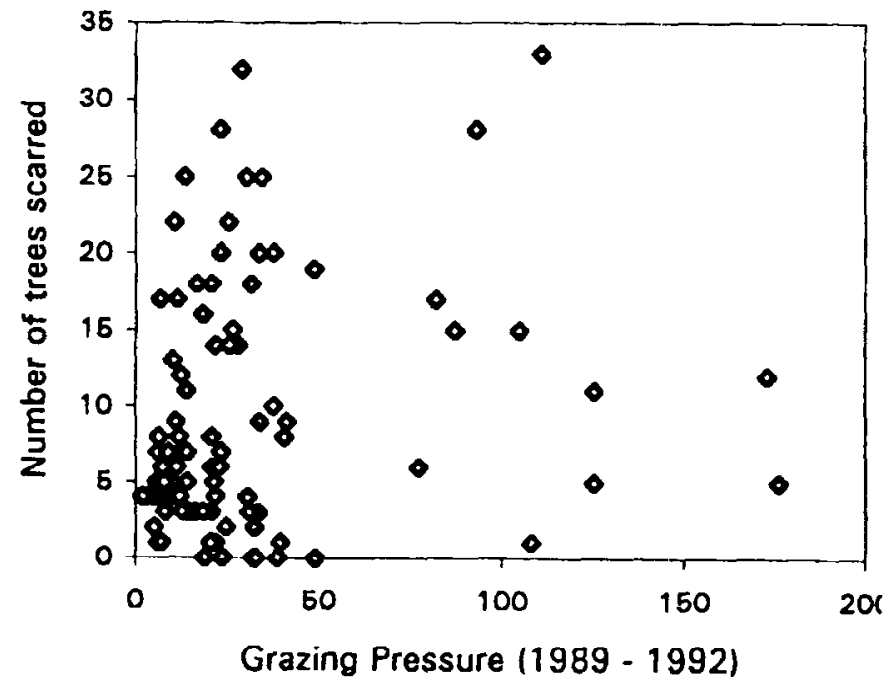

Fig. 5. Relationship $\left(P<0.001 ; r^{2}=0.36\right)$ of grazing pressure (AU $\mathrm{Mg}^{-1} \mathrm{ha}^{-1}$ ) and number of 100 sample trees scarred at Tunkwa Lake, Kamloops, British Columbia (1989-1992). 
Table 7. Coefficients of determination and levels of significance for regressions of tree damage on grazing pressure, 1989-1992, at Tunkwa Lake, Kamloops, British Columbia.

\begin{tabular}{|c|c|c|}
\hline Year & $\begin{array}{l}\text { Scarring During Interval With } \\
\text { Grazing Pressure During Interval }\end{array}$ & $\begin{array}{l}\text { Browsing During Interval With } \\
\text { Grazing Pressure During Interval }\end{array}$ \\
\hline $\begin{array}{l}108 \\
1989 \\
1990 \\
1991 \\
1992\end{array}$ & $\begin{array}{l}0.80 ; P=0.02 \\
0.94 ; P=0.00 \\
0.97 ; P=0.00 \\
0.63 ; P=0.06\end{array}$ & $\begin{array}{c}0.34 ; \mathrm{P}=0.22 \\
\text { no browsing } \\
\text { no browsing }\end{array}$ \\
\hline $\begin{array}{l}-\ldots . \\
1989 \\
1990 \\
1991 \\
1992\end{array}$ & $\begin{array}{c}0.84 ; P=0.01 \\
0.34 ; P=0.22 \\
\text { data missing } \\
0.54 ; P=0.10\end{array}$ & $\begin{array}{l}0.52 ; \mathrm{P}=0.11 \\
0.89 ; \mathrm{P}=0.00 \\
\text { data missing } \\
\text { no browsing }\end{array}$ \\
\hline $\begin{array}{l}-\ldots \\
1989 \\
1990 \\
1991 \\
1992\end{array}$ & $\begin{array}{l}0.93 ; P=0.00 \\
0.76 ; P=0.02 \\
0.83 ; P=0.01 \\
0.77 ; P=0.02\end{array}$ & $\begin{array}{c}0.80 ; \mathrm{P}=0.02 \\
0.74 ; \mathrm{P}=0.03 \\
\text { no browsing } \\
\text { no browsing }\end{array}$ \\
\hline $\begin{array}{l}-198 \\
1999 \\
1991 \\
1992\end{array}$ & $\begin{array}{l}085 ; P=0.01 \\
0.38 ; P=0.19 \\
0.52 ; P=0.01 \\
0.40 ; P=0.18\end{array}$ & $\begin{array}{c}0.75 ; P=0.03 \\
0.80 ; P=0.02 \\
\text { no browsing } \\
\text { no browsing }\end{array}$ \\
\hline $\begin{array}{l}0 . . \\
1989 \\
1990 \\
1991 \\
1991\end{array}$ & $\begin{array}{l}0.88 ; P=0.00 \\
0.80 ; P=0.02 \\
0.93 ; P=0.00 \\
0.64 ; P=0.06\end{array}$ & $\begin{array}{c}\text { no browsing } \\
0.30 ; P=0.26 \\
0.06 ; P=0.64 \\
\text { no browsing }\end{array}$ \\
\hline $\begin{array}{l}1989 \\
1990 \\
1991 \\
1992\end{array}$ & $\begin{array}{l}0.99 ; P=0.00 \\
0.47 ; P=0.13 \\
0.80 ; P=0.02 \\
0.28 ; P=0.28\end{array}$ & $\begin{array}{l}0.28 ; P=0.28 \\
\text { no browsing } \\
\text { no browsing } \\
\text { no browsing }\end{array}$ \\
\hline
\end{tabular}

ing pressure ranged between 2.0 and $40.8 \mathrm{AU} \mathrm{Mg}^{-1} \mathrm{ha}^{-1}$. No consistent pattern existed with basal scarring, which ranged between one and $11 \%$ of the trees per pasture. Basal scarring ranged from zero to $15 \%$ of trees pasture ${ }^{-1}$ in 1992 . No consistent pattern existed with grazing pressure, which varied between 14.6 and 125.6 $\mathrm{AU} \mathrm{Mg} \mathrm{Mg}^{-1}$.

Basal scarring and grazing pressure summarized for all pastures over the 4-year study (Fig. 5) indicates that less scarring occurred with lower grazing pressure $\left(P<0.001 ; r^{2}=0.36\right)$. Nonetheless, low basal scarring was occasionally associated with high grazing pressure. Similarly, high basal scarring was commonly associated with comparatively low grazing pressure.

\section{Discussion}

Cattle browsing on lodgepole pine seedlings peaked during the first year of grazing. This confirms a belief, based on experience, popularly held by British Columbia resource managers. Browsing increased with increasing stocking rate and with increasing grazing pressure. Stocking rate explained $71 \%$ of the variation in browsing damage, compared to only $38 \%$ for grazing pressure.

Basal scarring, resulting from trampling by cattle, peaked during the second year of grazing, and declined throughout the remaining 2 years of the study. This decline in trampling may have occurred as the trees grew taller, and became more visible to the cattle. Average tree height in $1989(22.4 \mathrm{~cm})$ increased to $29.6,36.3$, and $45.3 \mathrm{~cm}$ in 1990,1991 , and 1992 , respectively.
Indeed, basal scarring significantly correlated with stocking rate only during the first year of grazing.

Grazing pressure ( $\mathrm{AU} \mathrm{M \textrm {Mg } ^ { - 1 }} \mathrm{ha}^{-1}$ ), however, significantly correlated with basal scarring during all 4 years of the study, and likely provides a better predictor of trampling damage than does stocking rate (Animal Unit Days $\mathrm{ha}^{-1}$ ). During the peak year of trampling damage, stocking rate failed to provide a significant relationship with basal scarring.

Grazing pressure provided the most consistent explanation for basal scarring during the first year of grazing. Basal scarring generally increased to more than $10 \%$ of the sample trees when grazing pressure exceeded $12.0 \mathrm{AU} \mathrm{Mg}^{-1} \mathrm{ha}^{-1}$. This value compares favorably to the observations of Hart et al. (1988), who showed that average daily gains of steers in Wyoming declined when grazing pressure reached 29.0 steer days $\mathrm{Mg}^{-1} \mathrm{ha}^{-1}$. Presumably, as forage availability declines, cattle spend more time searching for forage (Scarnecchia et al. 1985), with increased probability that trampling of trees occurs. Eventually, forage availability relative to animal demand becomes so restricted that declines in average daily gain also occur.

The threshold grazing pressure value of $12.0 \mathrm{AU} \mathrm{Mg}^{-1} \mathrm{ha}^{-1}$ reported here for the first year of grazing cannot likely be extrapolated directly to other sites. Grazing pressure values, and associated basal scarring, are unquestionably influenced by many factors (e.g., pasture size, kind of grazing animal, forage species, tree height, water availability, topography, and weather patterns during the grazing period). Nonetheless, our work supports the observations of Scamecchia et al. (1985) that forage availability and grazing pressure provide a useful conceptual framework for predicting the potential for trampling damage of lodgepole pine seedlings by cattle.

\section{Literature Cited}

Atmospheric Environment Service. 1990. Monthly record of environmental observations in western Canada. Environment Canada. Donwsview, Ontario.

Hart, R.H., M.J. Samuel, P.S. Test, and M.A. Smith. 1988. Cattle, vegetation, and economic response to grazing systems and grazing pressure. J. Range Manage. 41:282-286.

Booysen, P. de V. 1967. Grazing and grazing management terminology in southern Africa. Proc. Grassl. Soc. Southern Afr. 2:45-57.

Lloyd, D.K., K. Angove, G. Hope, and C. Thompson. 1990. A guide to site interpretation for the Kamloops Forest Region. B.C. Ministr. Forest. Land Manage. Rep. 23. Victoria, BC.

McLean, A. and M.B. Clark. 1980. Grass, trees, and cattle on clear-cut logged areas. J. Range Manage. 33:213-217.

Nordstrom, L.O. 1984. The ecology and management of forest range in British Columbia. B.C. Ministr. Forest. Lands. Rep. 19.

Pitt, M.D. 1989. Integrated forest/range research - five year plan. B.C. Ministr. For. Res. Branch.

Province of British Columbia. 1995. Establishment to free growing guidebook, Kamloops Forest Region. Forest Practices Code of British Columbia. B.C. Ministr. For. and B.C. Ministr. Environ.

Scarnecchia, D.L. 1985. The relationship of stocking intensity and stocking pressure to other stocking variables. J. Range Manage. 38:558-559.

Scarnecchia, D.L., A.S. Nastis, and J.C. Malechek. 1985. Effects of forage availability on grazing behavior of heifers. J. Range Manage. 38:177-180

Wikeem, B., R. Newman, D. Quinton, M. Pitt, and P. Youwe. 1991. The effects of forage seeding and cattle grazing on early establishment of lodgepole pine - Project 3.55. FRDA Res. Memo 185. B.C. Ministr. For., Victuria. 3 pp. 